\title{
Frugivorous bats in the Colombian Caribbean region are reservoirs of the rabies virus
}

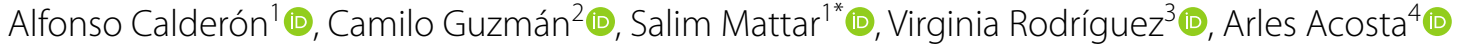 \\ and Caty Martínez ${ }^{4}$ (B)
}

\begin{abstract}
Background: Bats are an important ecological group within ecosystems. The rabies virus is a Lyssavirus, and haematophagous bats are the principal reservoir; however, the virus has also been detected in non-haematophagous bats. The objective was to determine the rabies virus in non-haematophagous bats in the Colombian Caribbean region.

Methods: In 2017, a cross-sectional study was carried out with a base-risk sampling in twelve geographic zones of the Colombian Caribbean area that included the main ecosystems of two departments. 286 bats were captured, which were euthanized with a pharmacological treatment following the ethical protocols of animal experimentation. The taxonomic identification was done with dichotomous keys. The necropsy was carried out at the capture site, and brain samples were kept in liquid nitrogen. The extraction of the RNA was carried out from the frozen brains with TrizoI $^{\mathrm{TM}}$; a fragment of $914 \mathrm{bp}$ of the glycoprotein $\mathrm{G}$ of the rabies virus was amplified with RT-PCR. The amplicons were sequenced with the Sanger method.
\end{abstract}

Results: Twenty-three genera of bats were identified, and, in two frugivorous, Artibeus lituratus and Artibeus planirostris, amplicons were obtained and sequenced as the rabies virus.

Conclusions: This is the first evidence of natural infection of the rabies virus in frugivorous bats in the Colombian Caribbean area; this result is important for the surveillance and control of rabies.

Keywords: Chiroptera, Ecosystems, Epidemiology, Public health, Transmission, Zoonoses

\section{Background}

Rabies is a zoonotic disease that affects humans through saliva, bites or scratches [1]. The natural hosts of the rabies virus include Carnivora and Chiroptera [2]. The rabies virus belongs to the genus Lyssavirus and produces fatal acute encephalitis in humans [3]. Rabies is distributed on all continents, except Antarctica [3]; once the symptoms appear, the disease is fatal [1]. Global mortality is estimated at 59.000 human cases per year, $95 \%$ of

\footnotetext{
${ }^{*}$ Correspondence: mattarsalim@hotmail.com

${ }^{1}$ Instituto de Investigaciones Biológicas del Trópico (IIBT), Facultad de Medicina Veterinaria y Zootecnia, Doctorado en Medicina Tropical, Universidad de Córdoba, Carrera 6 No 76-103., Monteria, Córdoba, Colombia

Full list of author information is available at the end of the article
}

these cases occur in Africa and Asia, mainly from dog bites [4]. In developed countries, wild species are the principal reservoirs, and, in domestic animals, mass vaccination prevents the spread of the virus [5].

Bats are an important ecological group in nature because of their ability to control insects, disperse seeds [6] and pollinate [7]. 70\% of bat species are insectivorous and widely distributed worldwide [8]. Bats are hosts of high viral diversity, with a high zoonotic potential [9]. The rabies virus and other Lyssavirus do not appear to cause disease in bats, suggesting co-evolution between the viruses and their hosts [10, 11]; high colony densities of up to 3000 bats per square meter [12] and repeated infections are likely to occur frequently, providing a mechanism for resistance to rabies [13]. Bats can carry a large number of infectious agents, but they do not suffer

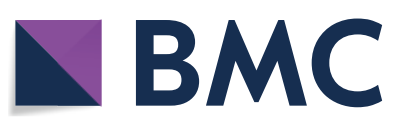

(c) The Author(s) 2019. This article is distributed under the terms of the Creative Commons Attribution 4.0 International License (http://creativecommons.org/licenses/by/4.0/), which permits unrestricted use, distribution, and reproduction in any medium, provided you give appropriate credit to the original author(s) and the source, provide a link to the Creative Commons license, and indicate if changes were made. The Creative Commons Public Domain Dedication waiver (http://creativecommons.org/ publicdomain/zero/1.0/) applies to the data made available in this article, unless otherwise stated. 
from the disease, and it is believed that the increase in body temperature as a result of flight increases the metabolic rate, activating mitochondria to trigger the immune cascade with interleukin production and prostaglandins, avoiding infection with the pathogens that they carry [14].

The haematophagous bats Desmodus rotundus, Diaemus youngi and Diphylla ecaudata are reservoirs of the rabies virus and are distributed from the Tropic of Cancer to the Tropic of Capricorn [15]. These species of haematophagous bats are involved in the transmission of rabies in the tropics. In Colombia, like other countries in the Caribbean, Central America and South America, the majority of cases of human rabies transmitted by haematophagous bats have been associated with $D$. rotundus [16].

There are two cases reported of human rabies apparently transmitted by non-hematophagous bats. The first was reported in the USA in 1953 [17] and the second one was in 1996 in Chile [18]. The serological and genetic characterization denoted that the reservoir in Chile was the insectivorous bat Tadarida brasiliensis [18]. In the Americas, there are several species of insectivorous, frugivorous, nectarivorous, omnivorous and carnivorous bats that have been reported as reservoirs for the rabies virus [19].

On the other hand, according to the Colombian Agriculture Institute (ICA), there have been 184 cases of encephalitis [20]; the National Institute of Health of Colombia (INS) reported 13 human cases compatible with encephalitis up to week 38 of 2018 [21]. There are several problems one of them is the sub-registrations report of animal cases that don't allow a full epidemiological analysis. Also the recollection methods of the sample are very deficient, resulting in a poor diagnosis at the laboratory level. On the other hand, recently in Colombia in some areas of the Departments of Cordoba and Sucre, bat bites were observed in cows and horses, and hematophagous bats were captured, in which the rabies virus was detected in the brains with a prevalence of $2 \%$ with Sellers staining technique and $13 \%$ with direct immunofluorescence [22, 23]. The sensitivity and specificity of immunohistochemistry (IHC) and direct immunofluorescence (DIF) depending on the clinical status of the pathology at the moment of the diagnosis; the sensitivity and specificity of $\mathrm{ICH}$ is $70 \%$ when Negri bodies are present and the DIF is of $100 \%$ [24]. Regarding the occurrence of the rabies virus in non-hematophagous bats, there have only been two previous studies in Colombia one in 1968 in San Vicente de Chucurí (Santander) in the low tropic of Magdalena River, a rabies virus was found in Carollia perspicillata [25]. The second one was reported in 2012 in the Western area of the country (Cali) in urban bats Molossus molossus and Eptesicus brasilensis [16]. In Cordoba and Sucre departments, there are no ecoepidemiological studies on the circulation of the rabies virus in non-hematophagous bats. The objective of this study was to detect the rabies virus in non-haematophagous bats in two departments of the Colombian Caribbean region.

\section{Methods}

\section{Type of study, study area and sampling}

In 2017, in two departments of the Colombian Caribbean region, a cross-sectional study was carried out with a base-risk sampling, for which 286 bats were captured. Based on the fact that, during 2014 and 2016 in the departments of Cordoba and Sucre, there were 146 cases of bovine rabies, according to the Colombian Agriculture Institute [26], 12 sampling sites were selected in these endemic areas for the rabies virus (Fig. 1). Of the 12 sampling sites, 8 were in Cordoba and 4 in Sucre; in both departments, the main ecosystems were included (Fig. 1).

\section{Capture of specimens}

The bats were captured using five mist nets for $4 \mathrm{~h}$ of sampling, which corresponded to $240 \mathrm{~h} /$ network. The bats were identified with dichotomous taxonomic keys based on morphometric parameters [27]. The bats were initially medicated with atropine $(0.005 \mathrm{mg} / \mathrm{kg}$, Laboratories $\mathrm{ZOO}^{\mathrm{TM}}$, Colombia) and acepromazine $(0.11 \mathrm{mg} /$ $\mathrm{Kg}$; Laboratories $\mathrm{ZOO}^{\mathrm{TM}}$, Colombia) using intramuscular administration and euthanized with an intracardiac overdose of $0.2 \mathrm{ml}$ of sodium pentobarbital (Invet ${ }^{\mathrm{TM}}$, Colombia). The dissection was performed at the capture site where the brains were removed and deposited in sterile ${\text { cryovials with } \text { Trizol }^{\mathrm{TM}} \text { (Invitrogen }}^{\mathrm{TM}}$ ) and kept in tanks with liquid nitrogen. To preserve the species, pregnant or lactating females were released.

\section{Molecular detection of the rabies virus}

The RNA extraction was performed with Trizol ${ }^{\mathrm{TM}}$ (Invitrogen) from 286 samples of brain tissues; the aliquots were resuspended in $150 \mu \mathrm{L}$ of nuclease-free water. The concentration of the RNA obtained with the NanoDrop 2000 equipment (Spectrophotometers ${ }^{\mathrm{TM}}$ ) was then quantified. The cDNA synthesis was done with the reverse transcriptase enzyme M-MLV (Invitrogen ${ }^{\mathrm{TM}}$ ) using random primers (Invitrogen ${ }^{\mathrm{TM}}$ ), following the recommendations of the manufacturers. Subsequently, a conventional PCR was carried out that amplified a fragment of the gen $G$ with the primers (Ga3222-4) (5'CGCTGCATTTTR TCARAGT3') and (Gb4119-39) (5'GGAGGGCACCAT TATTGGTMTC3'), which amplify a fragment of $914 \mathrm{bp}$ $[3,28]$. The initial denaturation was done at $94{ }^{\circ} \mathrm{C}$ for $5 \mathrm{~min}$, then 35 cycles at $94{ }^{\circ} \mathrm{C}$ for $45 \mathrm{~s}, 55^{\circ} \mathrm{C}$ for $45 \mathrm{~s}$ and $72{ }^{\circ} \mathrm{C}$ for $90 \mathrm{~s}$ and a final extension at $72{ }^{\circ} \mathrm{C}$ for $5 \mathrm{~min}$. 


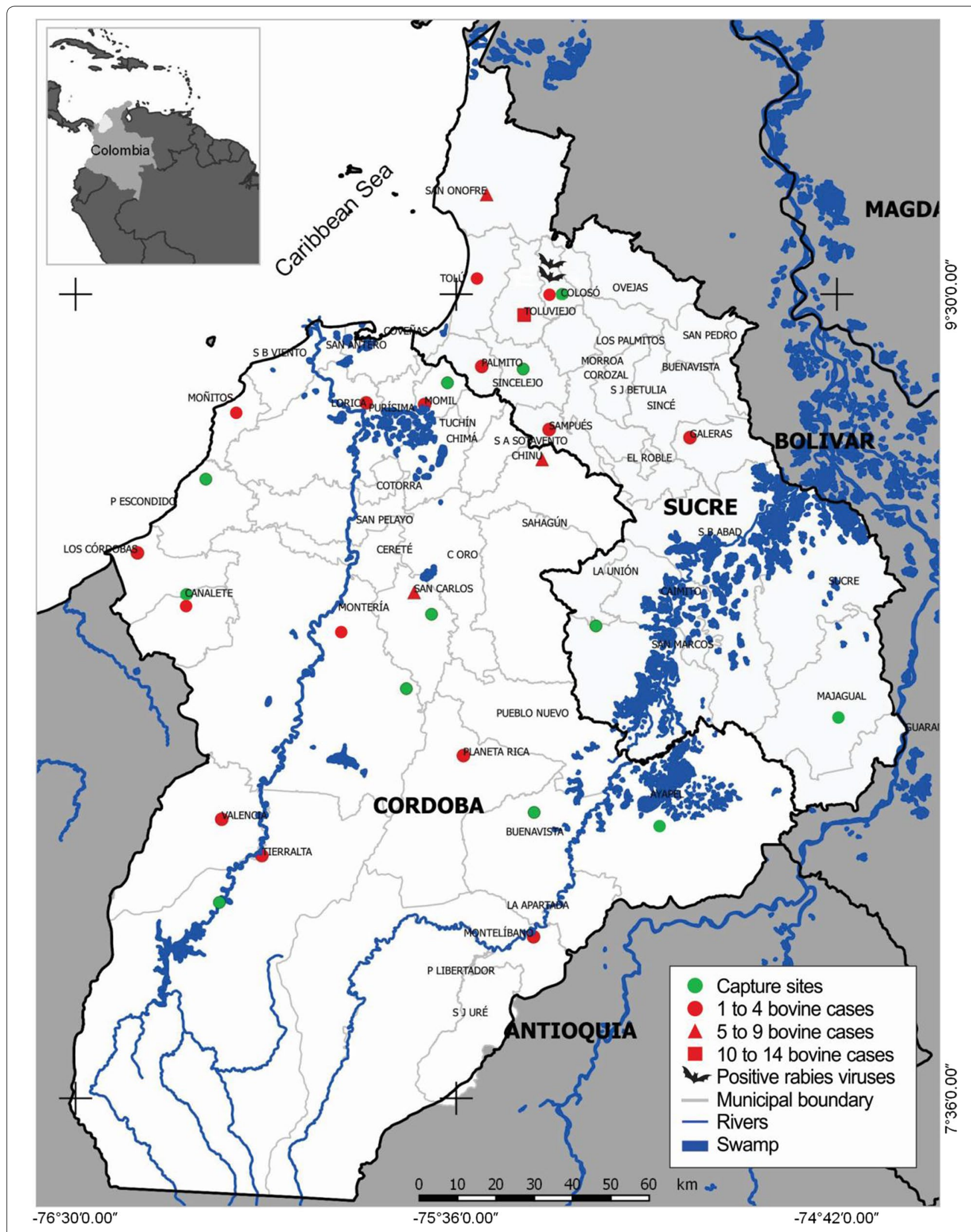

Fig. 1 Distribution of cases of bovine rabies in Cordoba and Sucre reported by ICA during 2014-2016 and sampling sites used in the present study 
As a control of species and internal control, complementary primers of a sequence of the mitochondrial gen $\mathrm{mt}$ DNA of bats were used [29]. As a positive control, RNA extracted with Trizol $^{\mathrm{TM}}$ (Invitrogen) was used from the vaccine (strain PM/WI38, Lyon, France), and molecular biology grade water was used as a negative control. Agarose-gel electrophoresis was carried out with the amplification products. The amplicons were sequenced with the Sanger method was carried in Korea $\left(\right.$ Macrogen $\left.^{\mathrm{TM}}\right)$.

\section{Phylogenetic analyzes}

The sequences were edited and aligned automatically with Geneious software (version 9.1.79), where two sequences of $793 \mathrm{bp}$ were obtained. These sequences were aligned with Clustal W, found in Mega7. For the phylogenetic reconstructions, 86 reference sequences available in the GenBank were used for typing by groups. The sequence of the vaccine strain was also included. The best evolution model was applied to explain the nucleotide diversity observed between the aligned sequences, and the phylogenetic reconstructions were done using Neighbor-Joining (NJ), Maximum Likelihood (ML) and Unweighted Pair Group Method with Arithmetic Mean (UPGMA) using the software MEGA7.

\section{Results}

In the twelve sampling sites, 286 bats were captured, distributed in six families and 23 species. Table 1 shows the distribution of the bats and their food habits. Amplicons of the glycoprotein $\mathrm{G}$ of the rabies virus were detected in two brains of frugivorous bats A. lituratus and A. planirostris, captured in Coloso, Department of Sucre (latitude $9.4980^{\circ} \mathrm{N}$, longitude $-75.3494^{\circ} \mathrm{W}$ ). Four $D$. rotundus specimens were captured in this study, two in San Carlos, Cordoba (latitude $8.7441^{\circ} \mathrm{N}$, longitude $-75.6563^{\circ} \mathrm{W}$ ) and two in Coloso (Sucre), both were negative for the rabies virus with the RT-PCR. The sequences detected in the frugivorous bats were recorded in the GenBank under the numbers MH763616 and MH763617. These two sequences were grouped within the clade $D$. rotundus or rabies virus of sylvatic origin (Fig. 2), with an average internal distance between the taxa of $3 \%$.

\section{Discussion}

The rabies virus was detected in two brains of frugivorous bats, A. lituratus and A. planirostris. These findings are consistent with a report for $A$. lituratus in Bolivia and A. planirostris in Argentina, Belize, Bolivia, Brazil, Guatemala, Mexico, Peru and Trinidad and Tobago, where in non-haematophagous bats have detected the rabies virus [19].

In the urban area of Capanema (Brazil), a high percentage of seropositivity (52.46\%) was detected in $A$. planirostris to the rabies virus, but the brain was not positive for the infection. This high seropositivity indicated that the rabies virus can be spread in urban areas [30]. Studies on insectivorous bats have shown protective neutralizing antibodies for several years; however, these antibodies would not prevent bats from becoming sick and dying of rabies [31]. It has also been proposed that large population sizes and overcrowded conditions in roosts facilitate intra- and interspecies transmission [32].

On the other hand, the phylogenetic analysis showed 304 variable sites of 793 analyzed sites, and a total of 203 parsimoniously informative sites were determined. The phylogenetic analyzes showed ten clades with an average distance of $14.3 \%$. The sequences MH763616 and MH763617 were grouped with $100 \%$ branch support within the sequences that are directly related to the rabies virus isolated from $D$. rotundus; this bat is the principal vector, with high viremia and the ability to infect other animals. D. rotundus uses different animal species to obtain the blood, or by with high grooming social interactions $[33,34]$ or by the sympatry when they share shelters [35]. The topology of the phylogenetic tree shows ten clades grouped by different hosts and the sequences of the viruses detected in them and coincide with that of Oliveira [3], who reported ten clades similar to the present study.

In non-hematophagous bats from Sao Paulo (Brazil), three antigenic variants were identified $(\mathrm{AgV}-3, \mathrm{AgV}-4$ and AgV-6), all previously identified in Latin America [36-38]. These variants represent reservoirs of the Latin American rabies virus maintained in populations of the bats Desmodus rotundus (AgV-3), Tadarida brasiliensis (AgV-4) and Lasiurus cinereus (AgV-6) [39]. In Colombia, three genetic variants were identified of urban rabies cases that involved dogs, humans and non-haematophagous bats. The Colombian variant I was found in the Andean region and in the Department of Arauca (close to Venezuelan border); in this department, the last case of rabies was detected in a dog in 1977, and mass vaccination is believed to have eliminated variant I. Variant II was detected in the Colombian Caribbean, and two cases of haematophagus bats were found, one in a human and another in a dog. Variant III was found in southern Colombia in the Department of Valle del Cauca in two insectivorous bats (M. molossus, E. brasiliensis), in three dogs and one human [40]. The sequences found in the present study (MH763616.1 and MH763617) possibly are related to group I to the vampire bat $D$. rotundus (AgV3). The circulation of the genetic variants of the rabies virus in bats and other mammals is important because it establishes the virus and determines the risks to public health. The rabies virus variants are a significant public health concern; thus, the entire rabies viruses are potentially 
Calderón et al. Ann Clin Microbiol Antimicrob ～（2019) 18:11

Page 5 of 8

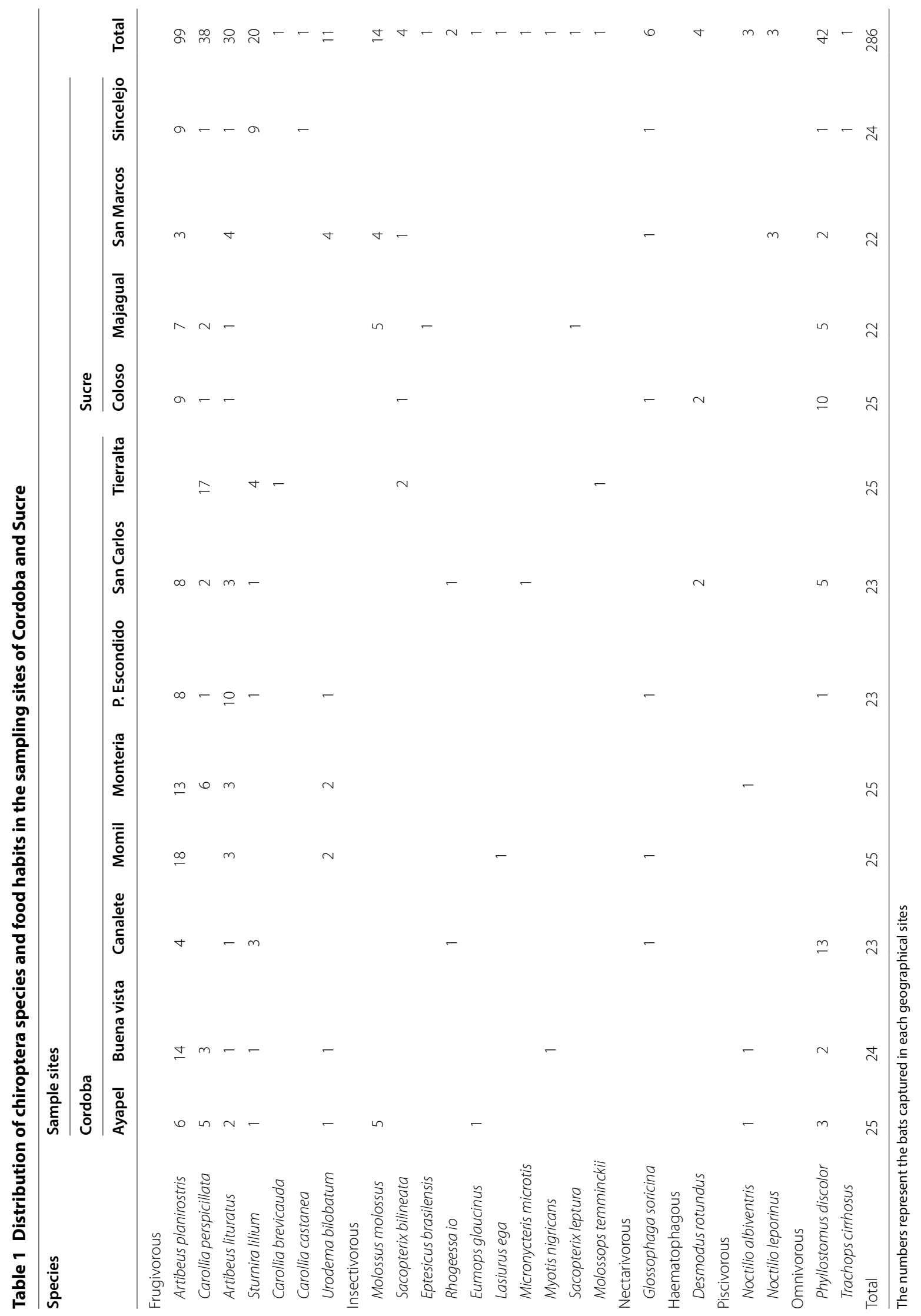




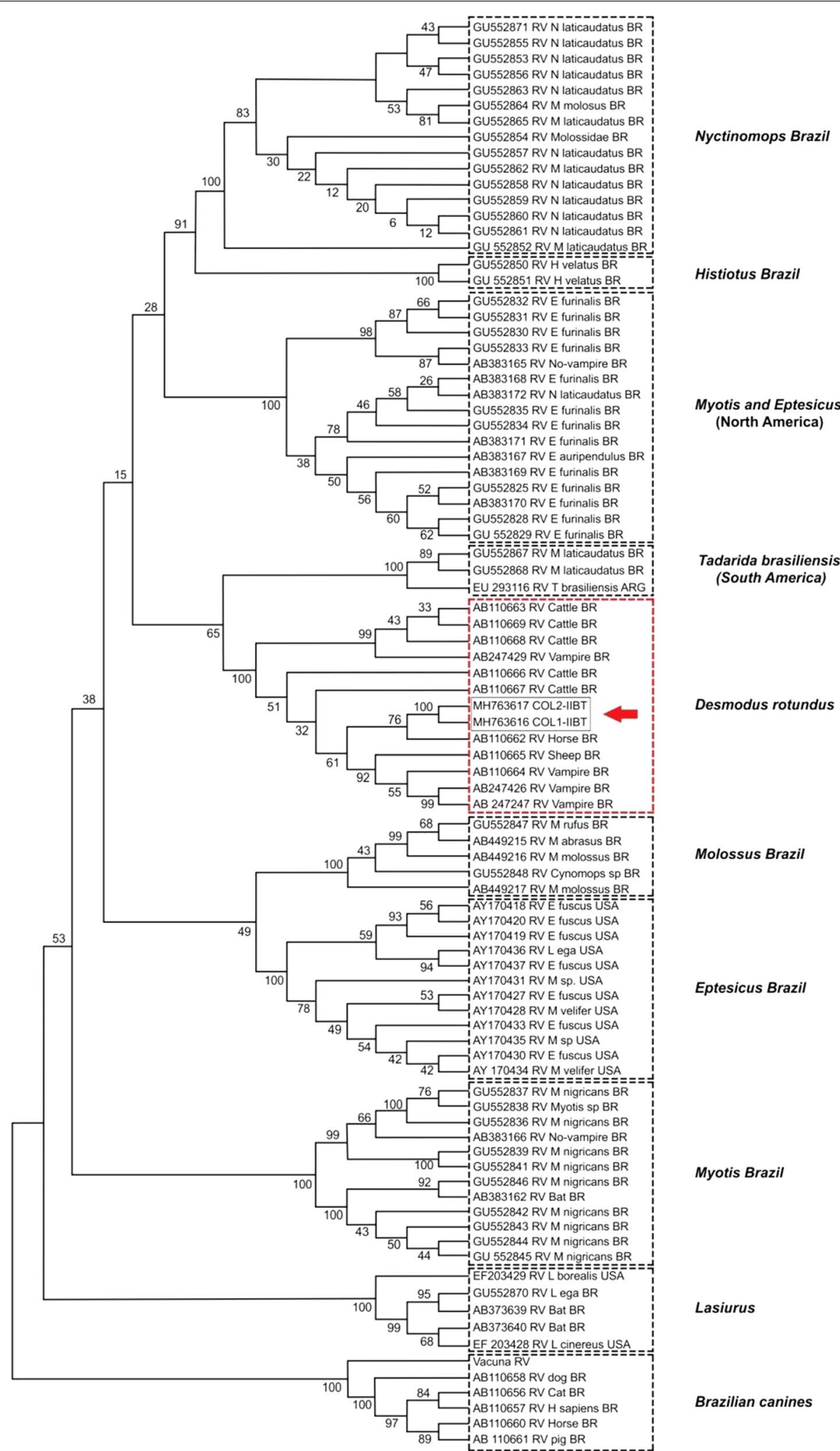

Fig. 2 Phylogenetic reconstruction with Maximum Likelihood for gen G of Lyssavirus; in the red box are the two sequences detected in the frugivorous bats of the present study in Coloso (Sucre) 
infectious for human's beings. Previous studies in Colombia showed that rabies virus transmitted in epizootic outbreaks, the viruses were closely genetic related. Hence, reservoirs can carry any infectious of rabies variant $[40,41]$. The present study cannot explain how it is the Colombian eco-epidemiological situation of rabies in different geographical areas like the Caribbean, Savannas (Llanos Orientales) and Pacific area for example, situation that it was explained by Hutter et al. in Costa Rica, who found association between animal rabies and rainy season [42].

The control of wild-origin zoonoses is limited by the insufficient knowledge on the biology of pathogens in the hosts, which coincides with pulses of viral excretion within bat populations produce densities changes and therefore contact rates [43]. Viruses can disappear locally, but persist globally through migration and new outbreaks in subsequent generations or decreased immunity, allowing circulation of the virus within the group or circulation of persistently infected bats. These concepts are applicable to a wide range of pathogens that affect humans and domestic and wild animals $[43,44]$.

\section{Conclusions}

This study presents the first molecular evidence of the natural infection of the rabies virus in frugivorous bats, A. lituratus and A. planirostris, captured in the Colombian Caribbean region. It is necessary to expand to other areas of the Colombian Caribbean and compare with other regions like the Pacific area, to observe better the biology and behavior of these animals and their involvement in the transmission of rabies.

\section{Abbreviations}

WHO: World Health Organization; ICA: Colombian Agriculture Institute; INS: National Institute of Health (Colombia); NJ: neighbor-joining; ML: maximum likelihood (ML); UPGMA: unweighted pair group method with arithmetic mean; MEGA: molecular evolutionary genetics analysis; AgV-3: antigenic variants 3; AgV-4: antigenic variants 4; AgV-6: antigenic variants 6.

\section{Authors' contributions}

All author contributed to the writing of the manuscript. In the design of the study ACR, CGT, SM and VRR. In the collection and identification of the samples in field ACR, CGT, AAR and CMB. Processing and analysis of samples in the laboratory ACR, CGT, VRR and AAR. In the analysis and interpretation of results $A C R, C G T, S M, V R R, A A R$ and $C M B$. All authors read and approved the final manuscript.

\footnotetext{
Author details

${ }^{1}$ Instituto de Investigaciones Biológicas del Trópico (IIBT), Facultad de Medicina Veterinaria y Zootecnia, Doctorado en Medicina Tropical, Universidad de Córdoba, Carrera 6 No 76-103., Monteria, Córdoba, Colombia. ${ }^{2}$ Instituto de Investigaciones Biológicas del Trópico (IIBT), Programa Regencia en Farmacia, Facultad de Ciencias de la Salud, Doctorado en Medicina Tropical, Universidad de Córdoba, Monteria, Colombia. ${ }^{3}$ Grupo de Investigaciones Microbiológicas y Biomédicas de Córdoba (GIMBIC). Programa de Bacteriología, Facultad de Ciencias de la Salud, Universidad de Córdoba, Monteria, Colombia.
}

${ }^{4}$ Producción Animal Tropical Facultad de Medicina Veterinaria y Zootecnia, Universidad de Córdoba, Monteria, Colombia.

\section{Acknowledgements}

We are grateful to the Universidad de Córdoba (Montería-Colombia). This study was kindly supported by Special Research Fund.

\section{Competing interests}

The authors declare that they have no competing interests.

\section{Availability of data and materials}

The datasets supporting the conclusions of this article are included within the article.

\section{Consent for publication}

Not applicable.

\section{Ethics approval and consent to participate}

This study was approved by the Ethics Committee of the Faculty of Veterinary Medicine and Zootechnics of the Universidad de Cordoba, Colombia (Certificate of Approval No. 0005/2016). The committee took into account the rules for research with non-commercial animals (ANLA).

\section{Funding}

The research was financed from a grant of vice-investigation of the Universidad de Cordoba (Colombia).

\section{Publisher's Note}

Springer Nature remains neutral with regard to jurisdictional claims in published maps and institutional affiliations.

Received: 20 December 2018 Accepted: 12 February 2019

Published online: 19 March 2019

\section{References}

1. Fooks AR, Cliquet F, Finke S, Freuling C, Hemachudha T, Mani RS, et al. Rabies. Nat Rev Dis Primers. 2017;3(1709):1. https://doi.org/10.1038/ nrdp.2017.91.

2. Paéz A, Rey G, Agudelo C, Dulce A, Parra E, Diaz GH, et al. Brote de rabia urbana transmitida por perros en el distrito de Santa Marta, Colombia, 2006-2008. Biomédica. 2009;29:424-36.

3. Oliveira RN, de Souza SP, Lobo RS, Castilho JG, Macedo Cl, Carnieli P Jr. et al. Rabies virus in insectivorous bats: implications of the diversity of the nucleoprotein and glycoprotein genes for molecular epidemiology. Virology. 2010;405:352-60.

4. World Health Organization. Rabies. 2018. Epidemiology and burden of disease. http://www.who.int/rabies/epidemiology/en/. Accessed 24 Oct 2018.

5. Elmore SA, Chipman RB, Slate D, Huyvaert KP, VerCauteren KC, Gilbert AT. Management and modeling approaches for controlling raccoon rabies: the road to elimination. PLoS Negl Trop Dis. 2017;11:e0005249. https://doi.org/10.1371/journal.pntd.0005249.

6. Jones G, Jacobs DS, Kunz TH, Willig MR, Racey PA. Carpe noctem: the importance of bats as bioindicators. Endang Species Res. 2009;8:93115. https://doi.org/10.3354/esr00182.

7. Sánchez-Casas N, Álvarez T. Palinofagia de los murciélagos del género Glossophaga (Mammalia: Chiroptera) en Mexico. Acta Zool Mex. 2000;81:23-62.

8. Barros MAS, Pessoa DMA, Rui AM. Habitat use and seasonal activity of insectivorous bats (Mammalia: Chiroptera) in the grasslands of southern Brazil. Zoologia. 2014;31:153-61. https://doi.org/10.1590/S1984 $-46702014000200006$.

9. Calderón A, Guzman C, Salazar-Bravo J, Figueiredo LT, Mattar S, Arrieta G. Viral zoonoses that fly with Bats: a review. 2016. J Parasite Biodiver. http://digitalcommons.unl.edu/manter/7.

10. O'Shea TJ, Cryan PM, Cunningham AA, Fooks AR, Hayman DT, Luis AD, et al. Bat flight and zoonotic viruses. Emerg Infect Dis. 2014;20:741-5. https://doi.org/10.3201/eid2005.130539. 
11. Baker ML, Schountz T, Wang LF. Antiviral immune responses of bats: a review. Zoonoses Public Health. 2013;60:104-16. https://doi.org/10.111 1/j.1863-2378.2012.01528.x

12. Luis AD, Hayman DT, O'Shea TJ, Cryan PM, Gilbert AT, Pulliam JR, et al. A comparison the bats and rodents as reservoirs of zoonotic viruses: are bats special? Proc Biol Sci. 2013; 289 20.122.753. https://doi.org/10.1098/ rspb.2012.2753.

13. Schatz J, Teifke JP, Mettenleiter TC, Aue A, Stiefel D, Müller T, et al. Lyssavirus distribution in naturally infected bats from Germany. Vet Microbiol. 2014;169:33-41. https://doi.org/10.1016/j.vetmic.2013.12.004.

14. Mattar S, González M. The amazing bats: friends, enemies or allies? Rev Cordoba. 2016;22:6177-9. https://doi.org/10.21897/rmvz.1125.

15. Torres C, Lema C, Dohmen FG, Beltrán F, Novaro L, Russo S, et al. Phylodynamics of vampire bat-transmitted rabies in Argentina. Mol Ecol. 2014;23(9):2340-52. https://doi.org/10.1111/mec.12728.

16. Núñez C, Páez A, Hernández C, Escobar H, Bonelo A. Transmisión del virus de la rabia entre murciélagos urbanos del departamento del Valle del Cauca, Colombia, 1999-2008. Infection. 2012;16:23-9.

17. Smith JS. Monoclonal antibody studies of rabies in insectivorous bats of the United States. Rev Infect Dis. 1988;10:S637-43. https://doi. org/10.1093/clinids/10.Supplement_4.S637.

18. Favi M, de Mattos CA, Yung V, Chala E, López LR, de Mattos CC. First case of human rabies in Chile caused by an insectivorous bat virus variant. Emerg Infect Dis. 2002;8:79-81. https://doi.org/10.3201/eid0801.010108.

19. Escobar LE, Peterson AT, Favi M, Yung V, Medina-Vogel G. Bat-borne rabies in Latin America. Rev Inst Med Trop Sao Paulo. 2015;57:63-72.

20. Instituto Colombiano Agropecuario. Informe de Sanidad animal 2015. Tomado de https://www.ica.gov.co/getattachment/4d163775-d3d847ab-92ba-fa5a0140bfdc/2015.aspx. Accessed 24 Oct 2018.

21. Instituto Nacional de Salud. Boletín Epidemiológico Semanal. https:// www.ins.gov.co/buscador-eventos/BoletinEpidemiologico/2018\%20 Bolet\%C3\%ADn\%20epidemiol\%C3\%B3gico\%20semana\%2041.pdf. Accessed 24 Oct 2018.

22. Betancourt C, Lengua JC, Calderón RA. Determinación del virus rábico en murciélagos hematófagos del Alto Sinú (Córdoba, Colombia). Veterinaria y Zootecnia. 2015;9:87-98. https://doi.org/10.17151/vetzo.2015.9.1.3.

23. Betancur HC, Calderón RA, Rodríguez VC. Presencia de virus rábico en murciélagos hematófagos en Colombia (Ciénaga de Oro y Sahagún, Córdoba). Revista Biosalud. 2016;15:17-24. https://doi.org/10.17151/biosa 2016.15.1.3.

24. Jurado GG, Montoya-Flórez L, Betancur C, Pedraza-Ordoñez F. Uso de la inmunohistoquímica como herramienta epidemiológica para el diagnóstico de rabia bovina a partir de casos no conclusivos. Rev MVZ Córdoba. 2012;17(2):3065-70.

25. Morales AA, Osorno-Mesa E, Bernal CC, Lleras PA. Aislamiento de virus rábico de murciélagos en Colombia. S A Caldasia. 1968;10:167-72.

26. Instituto Colombiano Agropecuario. Boletín epidemiológico semanal de alertas para acción inmediata. Mensuales 2014, 2015, 2016, 2017. https:// www.ica.gov.co/Areas/Pecuaria/Servicios/Epidemiologia-Veterinaria/Bol/ Epi.aspx. Accessed 24 Oct 2018.

27. Linares OJ. Murciélagos (orden Chiroptera) En: Mamíferos de Venezuela. Editorial Sociedad Conservacionista Audubon de Venezuela. Caracas. 1998. p. 349-590. ISBN: 9806326164.

28. Sato G, Itou T, Shoji Y, Miura Y, Mikami T, Ito M, et al. Genetic and phylogenetic analysis of glycoprotein of rabies virus isolated from several species in Brazil. J Vet Med Sci. 2004;66:747-53.
29. Ramírez NN, Alegre EA, Ruiz RM, De Biasio MB, Bastiani CE. Detección de leptospiras patógenas en tejido renal de murciélagos de Corrientes, Argentina. Rev vet. 2014;25:16-20.

30. Oliveira RS, Costa LJ, Andrade FA, Uieda W, Martorelli LF, Kataoka AP, et al. Virological and serological diagnosis of rabies in bats from an urban area in the Brazilian Amazon. Rev Inst Med Trop São Paulo. 2015;57:497-503. https://doi.org/10.1590/S0036-46652015000600006.

31. Zieger U, Cheetham S, Santana SE, Leiser-Miller L, Matthew-Belmar V, Goharriz H, et al. Natural exposure of bats in Grenada to rabies virus. Infect Ecol Epidemiol. 2017;7:1332935. https://doi.org/10.1080/20008 686.2017.1332935.

32. Calisher $\mathrm{CH}$, Childs JE, Field HE, Holmes KV, Schountz T. Bats: important reservoir hosts of emerging viruses. Clin Microbiol Rev. 2006;19:531-45. https://doi.org/10.1128/CMR.00017-06.

33. Johnson N, Aréchiga-Ceballos N, Aguilar-Setien A. Vampire bat rabies: ecology, epidemiology and control. Viruses. 2014;6:1911-28. https://doi. org/10.3390/v6051911.

34. Carter $\mathrm{G}$, Leffer L. Social grooming in bats: are vampire bats exceptional? PLOS ONE. 2015;10:e0138430. https://doi.org/10.1371/journal.pone.01384 30.

35. Uieda W, Harmani NMS, Silva NMS. Raiva em morcegos insetívoros (Molossidae) do Sudeste do Brasil. Ver Saúde Pública. 1995. https://doi. org/10.1590/s0034-89101995000500009.

36. Favi M, Nina A, Yung V, Fernandez J. Characterization of rabies virus isolates in Bolivia. Virus Res. 2003;97:135-40. https://doi.org/10.1016/j.virus res.2003.08.014.

37. Diaz AM, Papo S, Rodrigues A, Smith JS. Antigenic analysis of rabies-virus isolates from Latin America and the Caribbean. J Vet Med. 1994;41:15360. https://doi.org/10.1111/j.1439-0450.1994.tb00219.x

38. Mattos CA, Mattos CC, Smith JS, Miller ET, Papo S, Utrera A. Genetic characterization of rabies field from Venezuela. J Clin Microbiol. 1996;34:1553-8.

39. Albas A, Campos AC, Araujo DB, Rodriques CS, Sodré MM, Durigon EL, et al. Molecular characterization of rabies virus isolated from non-haematophagous bats in Brazil. Rev Soc Bras Med Trop. 2011;44:678-83.

40. Paéz A, Núñez C, García C, Boshell J. Epidemiología molecular de epizootias de rabia en Colombia, 1994-2002: evidencia de rabia humana y canina asociada a quirópteros. Biomédica. 2003;23:19-30.

41. Piñero C, Gury Dohmen F, Beltran F, Martinez L, Novaro L, Russo S, et al. High diversity of rabies viruses associated with insectivorous bats in Argentina: presence of several independent enzootics. PLoS NegI Trop Dis. 2012;6(5):e1635. https://doi.org/10.1371/journal.pntd.0001635.

42. Hutter SE, Brugger K, Sancho WH, González R, Aguilar O, León B. Rabies in Costa Rica: documentation of the Surveillance Program and the Endemic Situation from 1985 to 2014. Vector Borne Zoonotic Dis. 2016;16(5):334-41.

43. Plowright RK, Peel AJ, Streicker DG, Gilbert AT, McCallum H, Wood J, et al. Transmission or within-host dynamics driving pulses of zoonotic viruses in reservoir-host populations. PLoS Negl Trop Dis. 2016;10(8):e0004796. https://doi.org/10.1371/journal.pntd.0004796.

44. De la Alvis N. Rabia humana de origen canino y otras vergüenzas. Rev MVZ Córdoba. 2006;11(2):779-80.

Ready to submit your research? Choose BMC and benefit from:

- fast, convenient online submission

- thorough peer review by experienced researchers in your field

- rapid publication on acceptance

- support for research data, including large and complex data types

- gold Open Access which fosters wider collaboration and increased citations

- maximum visibility for your research: over $100 \mathrm{M}$ website views per year

At BMC, research is always in progress.

Learn more biomedcentral.com/submissions 